Island Studies Journal, Vol. 12, No. 1, 2017, 71-94

\title{
Sustainable local development on Aegean Islands: a meta-analysis of the literature
}

Sofia Karampela

University of the Aegean, Mytilini, Greece

karampela@env.aegean.gr

Charoula Papazoglou

University of the Aegean, Mytilini, Greece

geom09021@geo.aegean.gr

\section{Thanasis Kizos}

University of the Aegean, Mytilini, Greece

akizos@aegean.gr

and

Ioannis Spilanis

University of the Aegean, Mytilini, Greece

ispil@aegean.gr

\begin{abstract}
Sustainable local development is central to debates on socioeconomic and environmental change. Although the meaning of sustainable local development is disputed, the concept is frequently applied to island cases. Studies have recently been made of many local development initiatives in different contexts, with various methods and results. These experiences can provide valuable input on planning, managing, and evaluating sustainable local development on islands. This paper provides a literature review of positive and negative examples of sustainable local development for the Aegean Islands, Greece. Out of an initial 1,562 papers, 80 papers made the final selection based on theme, empirical approach, and recency. The results demonstrate a wide thematic variety in research topics, with tourism, agriculture, and energy being the most frequent themes, while integrated frameworks are largely absent. The literature includes a wide range of methods, from quantitative approaches with indicators and indexes to qualitative assessments, which blurs overall assessments in many instances.
\end{abstract}

Keywords: Aegean islands, economy, environment, sustainable local development, meta-analysis

https://doi.org/10.24043/isj.6

(C) 2017 - Institute of Island Studies, University of Prince Edward Island, Canada.

\section{Introduction}

Sustainability and sustainable development are notions that are widely used today in areas of research, policies, monitoring, and planning (Spilanis et al., 2009). Despite widespread agreement that 'sustainable development' is the desired goal of all policies and human societies, it is unclear how the general definitions can be translated into concrete and measurable policy goals. Moreover many issues need to be addressed to make sustainable development operational, such as the appropriate geographical scale for action and the development of effective tools that will help achieve sustainability (Kondyli, 2010). 
Methodologically, islands are ideal 'laboratories' for studying and measuring sustainability, with easily discernible limits and defined flows (Spilanis et al., 2009; Rodríguez et al., 2008). On the other hand, Huang et al. (2008) and Grydehøj and Kelman (2017) demonstrate the existence of "eco-island traps": small island communities are typically characterized by environmental, economic, and social vulnerability in practice. Many of these islands face particular economic and social development challenges, nowadays exacerbated by environmental issues due to anthropogenic activities. In fact, all of the characteristics of islands can also be perceived as a strategic opportunity for sustainable development or a chance to re-define and re-frame it. This is the starting point for the present paper: Islands are and/or can be attractive, and they are and/or can be sustainable (though not necessarily self-sufficient since, within current economic paradigms and applications, many islands cannot be sustainably developed; see Baldacchino \& Kelman, 2014). Yet this is not achieved by isolating islands from the global socioeconomic system, but instead by incorporating them into the system on terms that are sensitive and sympathetic to their islandness and their local development. According to Baldacchino and Kelman (2014), we need to move beyond the mono-dimensional characterization of so many threatened island 'paradises'.

This paper uses a meta-analysis of the literature on approaches to and case studies of sustainable development on Aegean islands to provide insight into what has 'worked' and what 'has not worked' as well as what has received attention within the literature. Ultimately, we wish to contribute towards re-framing sustainable development for islands.

\section{Methodology}

\subsection{Research approach}

With the goal of selecting case studies on different aspects of sustainable local development for the Aegean islands and of critically examining positive and negative aspects of these case studies, we followed a three-step approach.

First, we defined the title and the keywords for the search of documents dealing with sustainable local development in the Aegean Islands. The notion of sustainable local development has a history going back nearly two decades and has increasingly been translated into operational policy guidelines and measurable indicators. Examples are agricultural sustainability, urban sustainability, and transport sustainability (Girard \& Nijkamp, 2009). The terms used in the English language in the literature review were 'Aegean Island' OR 'Aegean' in article title, abstract, and keywords. The search was undertaken in early 2015 and yielded 1,562 documents. The search was done in the Scopus database and in the 'Archipelago' repository (http://archipelago.aegean.gr/, operated by University of the Aegean), in which mostly Greek researchers have submitted research. Specific locations or islands were not searched for due to widely different Latin transliterations of Greek island names (e.g., Thera, Thira, Santorini for the island of Santorini; Lesvos, Lesbos, Mytilene, Mytilini for the island of Lesvos; Samothraki, Samothrace for the island of Samothraki) and the large number of islands involved. This final list is partial and refers to a fraction of the papers in existence; nevertheless, we believe it provides an accurate and representative selection for the type of broader geographical analysis in sustainability approaches that this paper provides. Out of these documents we selected: (a) papers that referred to specific case studies of Greek Aegean islands; (b) papers with a timeframe of the $20^{\text {th }}$ and $21^{\text {st }}$ centuries. The final number of papers selected was 196.

In the second stage, we read the abstracts of the papers in order to identify sustainable local development approaches, resulting in a further narrowing of the 
selection to 80 papers. In the third stage, we studied full texts of the selected papers and classified the approaches under seven main themes. These were: the three dimensions of sustainable development: economy (with five sub-themes), society (with two subthemes), environment (with five sub-themes); integrated approaches to sustainable development/sustainability; and three more issues very important for islands: accessibility, transport, and attractiveness (Table 1). The final list of themes was derived by initial classifications from the keywords and the themes of each paper, which we afterwards categorized according to thematic relevance. These seven main themes (categories) were not exclusive, and each paper could be classified under more than one theme and/or sub-theme.

Figure 1: Location of the case study Aegean islands (Region Notio Aigaio $=$ South Aegean, and Region Vorio Aigaio = North Aegean)

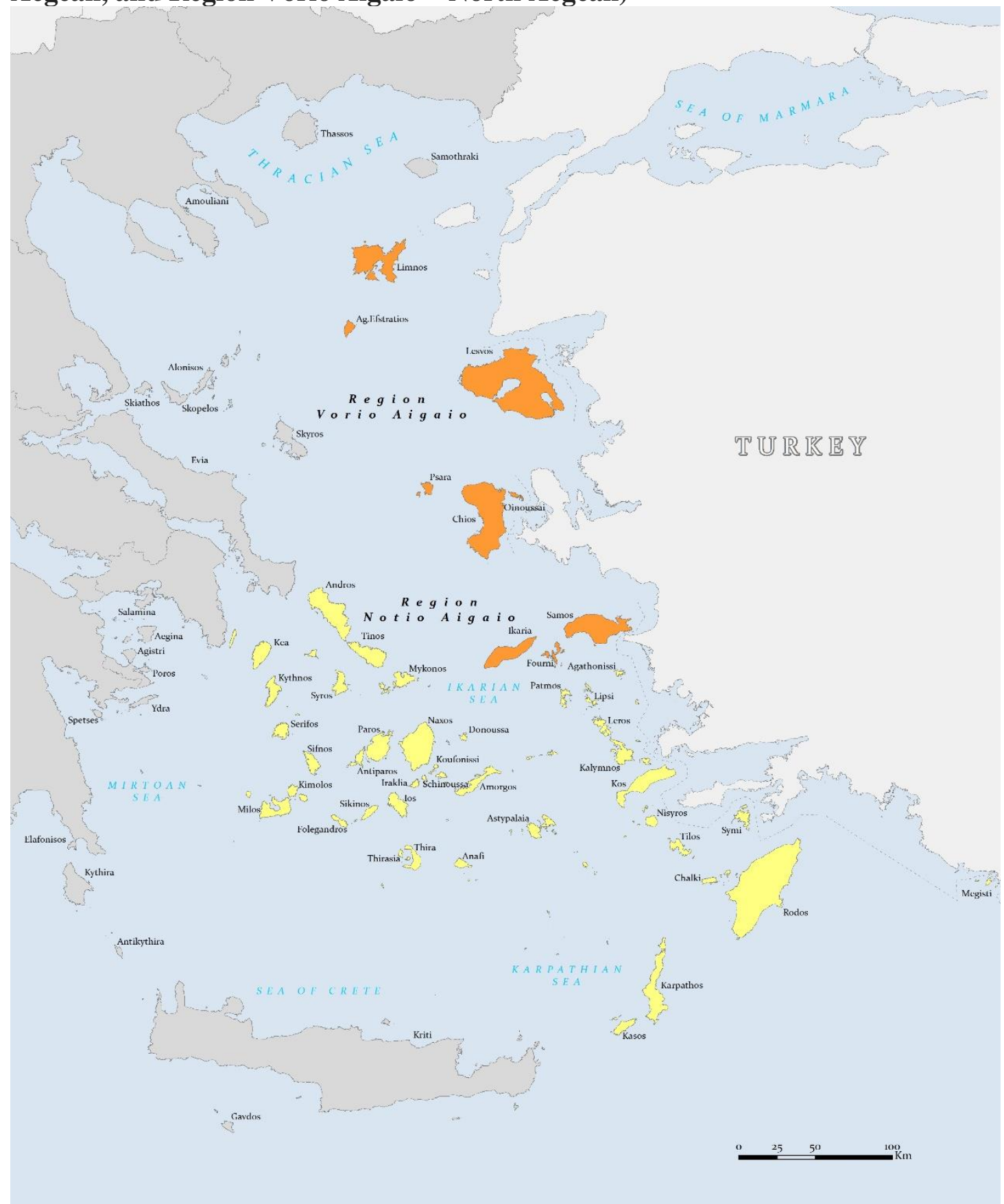

Source: translated from Spilanis \& Kizos, 2015. 


\subsection{The case studies area}

Constantakopoulou (2007, p. 2) writes:

The Aegean, according to Aelius Aristeides, has the best position in the world: it is located in the middle of the oikoumene and in the middle of the Greek world. Indeed, the history of the Greek world is in many ways the history of the Aegean sea. The Aegean sea, however is dominated by its islands; it is no coincidence that in the Ottoman period the Aegean sea was also called 'Adalar Denizi', Sea of islands.

Geographically, the Aegean islands occupy a space defined by the island of Crete in the south, mainland Greece in the north and west, and mainland Turkey in the east, a total land area of approximately $19,000 \mathrm{~km}^{2}$ (Karampela et al., 2015). Greek sovereign land includes islands and islets scattered across the Aegean and Ionian Seas, of which only 114 islands are inhabited.

\section{Results}

The terms that were found in the literature include not just 'sustainability', 'sustainable development', and 'sustainable local development', but also various sub-themes, for example, sustainability of energy, of agriculture, sustainable tourism development. The ability to exchange positive and negative experiences, knowledge, and practices could provide positive results for managing sustainable local development. The most papers are related to environmental aspects of sustainable development $(41 \%)$, followed by those related to economy (35\%), with the least reference to sustainability/sustainable development in a general sense (4.4\%), and accessibility (5.2\%).

Table 1: Frequencies of themes and sub-themes of the 80 selected papers

\begin{tabular}{|c|c|c|c|}
\hline Themes & Sub-themes & $\begin{array}{c}\text { Number } \\
\text { of } \\
\text { papers }\end{array}$ & $\begin{array}{c}\text { Total } \\
\text { Percentage }\end{array}$ \\
\hline \multirow{5}{*}{ Economy } & General & 7 & $5.2 \%$ \\
\hline & Tourism & 23 & $17.0 \%$ \\
\hline & Agriculture & 14 & $10.4 \%$ \\
\hline & Marine & 2 & $1.5 \%$ \\
\hline & Employment & 1 & $0.7 \%$ \\
\hline \multirow{2}{*}{ Society } & General & 8 & $5.9 \%$ \\
\hline & Social capital & 3 & $2.2 \%$ \\
\hline \multirow{5}{*}{ Environment } & General & 22 & $16.3 \%$ \\
\hline & Resources & 3 & $2.2 \%$ \\
\hline & Landscape & 12 & $8.9 \%$ \\
\hline & Energy & 15 & $11.1 \%$ \\
\hline & Water & 3 & $2.2 \%$ \\
\hline \multicolumn{2}{|c|}{$\begin{array}{l}\text { Sustainable development / } \\
\text { sustainability }\end{array}$} & 6 & $4.4 \%$ \\
\hline \multicolumn{2}{|l|}{ Accessibility } & 7 & $5.2 \%$ \\
\hline \multicolumn{2}{|l|}{ Transport } & 8 & $5.9 \%$ \\
\hline \multicolumn{2}{|l|}{ Attractiveness } & 1 & $0.7 \%$ \\
\hline \multicolumn{2}{|l|}{ Sum } & 135 & $100.0 \%$ \\
\hline
\end{tabular}

Source: authors 
The articles were also classified according to the geographic area that they include. Most of the papers (81) refer to case studies of specific islands (see Figure 2), including 36 different islands of the Aegean Sea (Table 2), and 54 of the papers refer to multiple Aegean islands and chains, such as the Dodecanese, the Cyclades, and the Northern Aegean region. Most references are to large administrative units, usually due to a lack of local data (especially in economy themes). In accordance with the typology of the Aegean islands adapted from Spilanis and Kizos (2015), findings also indicated that the papers most frequently examine case studies of 'medium-sized' islands (see Table 2). In contrast, references for the North Greek coastal islands of Thasos and Samothraki did not exist during the timeframe of our literature review.

Energy seems to be the most-analyzed topic concerning sustainable development for Aegean islands. Case studies of 'medium', 'small', and 'very small' islands showed that the estimation of energy efficiency and the production of secure and environmentally friendly energy sources are important topics for sustainable local development.

Lesvos island appears to be the most-used case study, either as a part of the North Aegean islands NUTS II region or as a single study area. This is related to (a) the location of the island (Lesvos is the biggest island in the Northern Aegean and therefore has more services available locally), and (b) the establishment of the University of the Aegean on various islands (Lesvos, Chios, Samos, Limnos, Syros, Rodos) provides the opportunity for more local research.

Table 2: Typology of the case study Aegean islands according to size and population.

\begin{tabular}{|c|c|c|c|c|c|}
\hline $\begin{array}{l}\text { Area/ } \\
\text { Population }\end{array}$ & $\begin{array}{l}\text { Very big } \\
(>500,000 \\
\text { inhabitants })\end{array}$ & $\begin{array}{l}\text { Big } \\
(500,000- \\
50,000 \\
\text { inhab. }\end{array}$ & $\begin{array}{l}\text { Medium } \\
(\mathbf{5 , 0 0 0 -} \\
\mathbf{5 0 , 0 0 0} \\
\text { inhab. })\end{array}$ & $\begin{array}{l}\text { Small } \\
(750-5,000 \\
\text { inhab. })\end{array}$ & $\begin{array}{l}\text { Very small } \\
\text { (750> } \\
\text { inhab.) }\end{array}$ \\
\hline $\begin{array}{l}\text { Very big } \\
(>1,000 \\
\left.\mathbf{k m}^{2}\right) \\
\end{array}$ & Crete & $\begin{array}{l}\text { Lesvos, } \\
\text { Rodos }\end{array}$ & & & \\
\hline $\begin{array}{l}\text { Big } \\
(500-1,000 \\
\text { km }^{2}\end{array}$ & & Chios & & & \\
\hline $\begin{array}{l}\text { Medium } \\
(100-500 \\
\left.\mathbf{k m}^{2}\right)\end{array}$ & & & $\begin{array}{l}\text { Samos, } \\
\text { Ikaria, } \\
\text { Limnos, } \\
\text { Paros, } \\
\text { Andros, } \\
\text { Naxos, } \\
\text { Kalymnos, } \\
\text { Kos } \\
\end{array}$ & $\begin{array}{l}\text { Skyros, } \\
\text { Ios, } \\
\text { Milos }\end{array}$ & \\
\hline $\begin{array}{l}\text { Small } \\
(100-50 \\
\left.\mathbf{k m}^{2}\right)\end{array}$ & & & $\begin{array}{l}\text { Santorini, } \\
\text { Mykonos, } \\
\text { Syros, } \\
\text { Leros }\end{array}$ & $\begin{array}{l}\text { Sifnos, } \\
\text { Astypalea, } \\
\text { Tilos, } \\
\text { Symi }\end{array}$ & \\
\hline $\begin{array}{l}\text { Very small } \\
\left(50 \mathrm{~km}^{2}>\right)\end{array}$ & & & Skiathos & $\begin{array}{l}\text { Oinousses, } \\
\text { Fournoi, } \\
\text { Nisyros, } \\
\text { Antiparos, }\end{array}$ & $\begin{array}{l}\text { Ag. } \\
\text { Efstratios, } \\
\text { Psara, } \\
\text { Donoussa, }\end{array}$ \\
\hline
\end{tabular}




\begin{tabular}{|l|l|l|l|l|}
\hline & & & Patmos & Thirasia, \\
& & & & Chalki, \\
& & & & Gavdos, \\
Antikythera
\end{tabular}

Source: Adapted from Spilanis \& Kizos, 2015.

In Table 3, the content of the papers, their most important issues, and their findings are presented per sub-theme in more detail. The sample includes few methodological papers, and most papers in our sample are case studies of one or more sub-themes in one or a few islands, especially for energy, tourism, and environment.

Table 3: Presentation of the papers' content for themes and sub-themes.

\begin{tabular}{|c|c|c|}
\hline $\begin{array}{c}\text { Theme / } \\
\text { sub-theme }\end{array}$ & Most important issue(s) presented & $\begin{array}{c}\text { Most important } \\
\text { findings }\end{array}$ \\
\hline Economy & $\begin{array}{l}\text { methodological tools with composite indexes } \\
\text { that go beyond GDP per capita, comparing the } \\
\text { state and attractiveness of island administrative } \\
\text { units (59); applying an expanded version of the } \\
\text { DPSR approach on Paros and Kos (58); or } \\
\text { using systems analysis to integrate all three } \\
\text { sustainable development dimensions (24); } \\
\text { socio-economic impacts (for designated food } \\
\text { products (72); for Greek return migration to } \\
\text { East Aegean islands (47); for telecommunications } \\
\text { connectivity and cost (6)); } \\
\text { the effectiveness of development policies (56) } \\
\text { for European Regional Development Fund } \\
\text { projects. }\end{array}$ & $\begin{array}{l}\text { For tourism: lack } \\
\text { of clear and } \\
\text { operational } \\
\text { definitions of } \\
\text { sustainable } \\
\text { tourism lead to } \\
\text { confusion about } \\
\text { its practical } \\
\text { meaning and } \\
\text { how it can be } \\
\text { achieved (55). } \\
\text { The monoculture } \\
\text { of tourism on } \\
\text { quite a few }\end{array}$ \\
\hline Toul & $\begin{array}{l}\text { tourism supply (tourism identities (34); spatial } \\
\text { transformations and tourism carrying capacity } \\
\text { (61); regional tourism development and policy } \\
\text { (66); women's cooperatives and their } \\
\text { contribution to local development (73); the } \\
\text { 'nature' of agrotourism in Greece (20); and } \\
\text { hotel employees' and postgraduate students' } \\
\text { representations of 'tourism development' (31)); } \\
\text { tourism demand (where residents and/or } \\
\text { visitors' views on different issues are studied: } \\
\text { on environmental impacts of eco-tourism (53); } \\
\text { on cultural tourism services (51); on quality of } \\
\text { services (38); on the image of a tourist } \\
\text { destination (62); on tourism infrastructure (64); } \\
\text { on the cementation of beaches (77), while (39) } \\
\text { and (1) discuss travel patterns, motivations, } \\
\text { activities, norms, beliefs, appearance, and forms } \\
\text { of social interaction); } \\
\text { impacts of tourism activity on many different } \\
\text { issues ((55) provide an overall assessment } \\
\text { method; (54), (69), and (60) of tourism } \\
\text { infrastructures \& facilities on the environment; } \\
\text { (48) analyses the extraordinary case urban }\end{array}$ & $\begin{array}{l}\text { islands affects all } \\
\text { other economic } \\
\text { activities, but } \\
\text { alternative forms } \\
\text { of tourism in } \\
\text { general were of } \\
\text { limited analysis } \\
\text { (e.g. (1); (55); } \\
\text { (51)); with a } \\
\text { special mention } \\
\text { in agrotourism } \\
\text { (20), where } \\
\text { networking and } \\
\text { synergies are } \\
\text { lacking. } \\
\text { Islands' branding, } \\
\text { destination } \\
\text { image, and } \\
\text { identity with few } \\
\text { references (34); } \\
\text { (62). } \\
\text { Information } \\
\text { technology has } \\
\end{array}$ \\
\hline
\end{tabular}




\begin{tabular}{|c|c|c|}
\hline $\begin{array}{c}\text { Theme / } \\
\text { sub-theme }\end{array}$ & Most important issue(s) presented & $\begin{array}{c}\text { Most important } \\
\text { findings }\end{array}$ \\
\hline & $\begin{array}{l}\text { sprawl in Mykonos; (67) study impacts of } \\
\text { tourism employment on taxation; (75) propose } \\
\text { alternative impact scenarios (80); and (27) } \\
\text { impacts on agriculture). }\end{array}$ & $\begin{array}{l}\text { been considered } \\
\text { as a factor that } \\
\text { can potentially } \\
\text { reduce }\end{array}$ \\
\hline Agriculture & $\begin{array}{l}\text { - different cultivation practices (soil fertility (74), } \\
\text { comparisons between island and continental } \\
\text { practices (30); and the role of 'traditional' olive } \\
\text { plantations on economic, social, and } \\
\text { environmental farm household characteristics } \\
\text { (16)); } \\
\text { products and local / rural development ((72) } \\
\text { presents a designated cheese product; (11) } \\
\text { Chios mastic; (22) compare designated and } \\
\text { 'conventional' olive oils; and (73) the economic } \\
\text { performance of women cooperatives); } \\
\text { tourism vs. farming activities ((27) discuss } \\
\text { maintenance or abandonment of olive tree } \\
\text { cultivation and population changes with } \\
\text { presence or absence of tourism; and (20) } \\
\text { present the relation between agrotourism and } \\
\text { farming activities); } \\
\text { the rural landscape ((5) discuss the correlation } \\
\text { between terrace construction and changing } \\
\text { human population; and (21) the landscape } \\
\text { changes in olive plantations at different levels). }\end{array}$ & $\begin{array}{l}\text { seasonality (39). } \\
\text { Alternative } \\
\text { policies to } \\
\text { improve the } \\
\text { effectiveness of } \\
\text { the application of } \\
\text { a new tax policy } \\
\text { are suggested } \\
\text { (75); and } \\
\text { measures that } \\
\text { can lead to } \\
\text { balanced tourism } \\
\text { development } \\
\text { (67). } \\
\text { Agriculture is } \\
\text { declining, but } \\
\text { there are still } \\
\text { some positive } \\
\text { and successful } \\
\text { production } \\
\text { examples. The }\end{array}$ \\
\hline Marine & $\begin{array}{l}\text { - } \begin{array}{l}\text { supply ((76) discuss diversity and population } \\
\text { density of sponges); } \\
\text { demand ((44) analyze consumers' behaviour } \\
\text { towards organic aquaculture products). }\end{array} \\
\end{array}$ & $\begin{array}{l}\text { absence of } \\
\text { consensus and } \\
\text { common } \\
\text { management }\end{array}$ \\
\hline Employment & $\begin{array}{l}\text { regional tourism inequalities (reasons, degree of } \\
\text { intensity, etc.) according to the rate of hotel and } \\
\text { restaurant employment, which in Greece } \\
\text { represents a big percentage of total employment } \\
\text { in the field of tourism (67). }\end{array}$ & $\begin{array}{l}\text { among the } \\
\text { different actors } \\
\text { across the supply } \\
\text { chains is noted } \\
\text { as both a } \\
\text { problem and } \\
\text { constraint (22). }\end{array}$ \\
\hline Society & $\begin{array}{l}\text { 'social' indicators ((58) identify five factors } \\
\text { including the number of active inhabitants; } \\
\text { unemployment; job positions; incomes; } \\
\text { population size and age structure; while (24) } \\
\text { considered population size, age structure, and } \\
\text { social cohesion, related with welfare, equity, } \\
\text { and collective action); } \\
\text { society and tourism (ecotourism and how it can } \\
\text { improve welfare locally (53)); } \\
\text { return migration (47); } \\
\text { marriage, family formation and dissolution, and } \\
\text { life styles (14); } \\
\text { telecommunications (6); }\end{array}$ & $\begin{array}{l}\text { Although many } \\
\text { papers argue that } \\
\text { regional } \\
\text { governance, } \\
\text { partnership } \\
\text { building (15), } \\
\text { participatory } \\
\text { planning (4), } \\
\text { consensus- } \\
\text { building (50), } \\
\text { and the critical } \\
\text { role of social } \\
\text { agents (13) are } \\
\end{array}$ \\
\hline
\end{tabular}




\begin{tabular}{|c|c|c|}
\hline $\begin{array}{c}\text { Theme / } \\
\text { sub-theme }\end{array}$ & Most important issue(s) presented & $\begin{array}{l}\text { Most important } \\
\text { findings }\end{array}$ \\
\hline & $\begin{array}{l}\text { the critical role of social agents and non-state } \\
\text { actors in policy-making and new forms of } \\
\text { regional governance (15); (13). }\end{array}$ & \multirow[b]{2}{*}{$\begin{array}{l}\text { important for } \\
\text { sustainable local } \\
\text { development, } \\
\text { few offer } \\
\text { insights or } \\
\text { prescribe } \\
\text { solutions. } \\
\text { Overall poor } \\
\text { Greek } \\
\text { cooperation and } \\
\text { networks } \\
\text { experience, } \\
\text { especially at the } \\
\text { regional level } \\
\text { (20), directly } \\
\text { linked to the lack } \\
\text { of information } \\
\text { and intermediary } \\
\text { institutions that } \\
\text { promote } \\
\text { dialogue and } \\
\text { participation of } \\
\text { different social } \\
\text { groups in } \\
\text { planning } \\
\text { procedures (15). } \\
\text { Societal aspects } \\
\text { of renewable } \\
\text { energy (and } \\
\text { water) systems } \\
\text { on islands are } \\
\text { recognized as } \\
\text { equally } \\
\text { important as } \\
\text { technical aspects, } \\
\text { therefore } \\
\text { ensuring } \\
\text { participation of } \\
\text { local } \\
\text { stakeholders } \\
\text { (41); (9) already } \\
\text { from the early } \\
\text { stages (4) is very } \\
\text { important. }\end{array}$} \\
\hline $\begin{array}{l}\text { Social } \\
\text { capital }\end{array}$ & $\begin{array}{l}\text { forms in rural settlements (78); } \\
\text { regional governance (15); and } \\
\text { consensus-building, or new 'intellectual, social, } \\
\text { and political capital' (50). }\end{array}$ & \\
\hline Environment & $\begin{array}{l}\text { methodological tools, including indicators (58); } \\
\text { nutrient cycles of ecosystems (2); runoff and } \\
\text { soil erosion modeling (3); vegetation analysis } \\
\text { (7), environmental scenarios (10); landscape } \\
\text { modeling (12); qualitative assessments (16); }\end{array}$ & $\begin{array}{l}\text { Tourism seen } \\
\text { with double role: } \\
\text { exerting } \\
\text { pressures (54), } \\
\text { but also } \\
\end{array}$ \\
\hline
\end{tabular}




\begin{tabular}{|c|c|c|}
\hline $\begin{array}{c}\text { Theme / } \\
\text { sub-theme }\end{array}$ & Most important issue(s) presented & $\begin{array}{l}\text { Most important } \\
\text { findings }\end{array}$ \\
\hline & $\begin{array}{l}\text { (18); and composite indicators in a policy } \\
\text { context (24); } \\
\text { environmental technology and management, } \\
\text { including land-cover change (58), land-use } \\
\text { patterns and visibility (52), landscape } \\
\text { composition and configuration (8), soft } \\
\text { computing methods for erosion risk (17); } \\
\text { abandonment (70); (48); (42); (54); (27); (71); } \\
\text { products, including consumers' behaviour } \\
\text { towards organic aquaculture products (44) and } \\
\text { natural sponges (76). }\end{array}$ & $\begin{array}{l}\text { 'alternative' } \\
\text { forms potentially } \\
\text { positive for local } \\
\text { development } \\
\text { (55); (20); (39); } \\
\text { Housing pressure } \\
\text { higher on islands } \\
\text { with more } \\
\text { tourism, but also } \\
\text { on islands of } \\
\text { smaller size (54); }\end{array}$ \\
\hline Resources & $\begin{array}{l}\text { - } \text { diversity and population density of sponges } \\
\text { (76); } \\
\text { - aquaculture products (44); } \\
\text { - beach sediment cementation (77). }\end{array}$ & $\begin{array}{l}\text { 'second home' } \\
\text { sprawl rather } \\
\text { limited with } \\
\text { exceptions such }\end{array}$ \\
\hline Landscape & $\begin{array}{l}\text { - landscape changes }(63) ;(70) ;(48) ;(42) ;(5) ; \\
\text { (8); (13); (21); (23); } \\
\text { - landscape analysis }(52) ;(71) ;(12) .\end{array}$ & $\begin{array}{l}\text { as Mykonos } \\
(48) ; \\
\text { - Modeling can }\end{array}$ \\
\hline Energy & 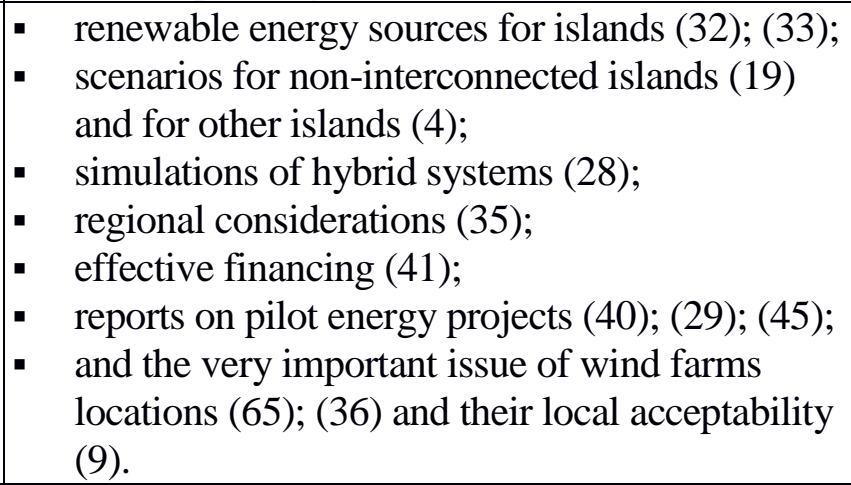 & $\begin{array}{l}\text { help in } \\
\text { determining } \\
\text { relationship of } \\
\text { agricultural } \\
\text { practices and } \\
\text { Mediterranean } \\
\text { ecosystems (3); } \\
\text { Locally focused } \\
\text { policies, such as } \\
\text { agri- }\end{array}$ \\
\hline Water & $\begin{array}{l}\text { hybrid energy water desalination systems (28); } \\
\text { - } \quad \text { photovoltaic micro-hydraulic systems (29); } \\
\text { financing issues (41). }\end{array}$ & $\begin{array}{l}\text { environmental } \\
\text { measures can } \\
\text { provide solutions } \\
\text { to sensitive } \\
\text { areas, such as the } \\
\text { Aegean islands } \\
\text { (23); } \\
\text { In most islands } \\
\text { there is a high } \\
\text { potential for } \\
\text { renewable } \\
\text { energy sources } \\
\text { (32); with high } \\
\text { investment for } \\
\text { installation, but } \\
\text { this should be } \\
\text { treated with } \\
\text { minor } \\
\text { importance when } \\
\text { economic and } \\
\text { social impacts }\end{array}$ \\
\hline
\end{tabular}




\begin{tabular}{|c|c|c|}
\hline $\begin{array}{c}\text { Theme / } \\
\text { sub-theme }\end{array}$ & Most important issue(s) presented & $\begin{array}{l}\text { Most important } \\
\text { findings }\end{array}$ \\
\hline & & $\begin{array}{l}\text { are also counted } \\
\text { (29); } \\
\text { Many barriers to } \\
\text { renewable } \\
\text { energy, including } \\
\text { grid } \\
\text { infrastructure, } \\
\text { complex } \\
\text { licensing system, } \\
\text { local reactions, } \\
\text { and lack of } \\
\text { financial } \\
\text { advantages (33); } \\
\text { (35). }\end{array}$ \\
\hline $\begin{array}{l}\text { Cross } \\
\text { sectoral }\end{array}$ & $\begin{array}{l}\text { measurement tools }(58) ;(24) ; \\
\text { - } \quad \text { tourism and sustainable development }(61) ;(55) ; \\
\text { energy and sustainable development }(33)\end{array}$ & $\begin{array}{l}\text { Agricultural } \\
\text { sustainable } \\
\text { systems seem to } \\
\text { depend on } \\
\text { economic } \\
\text { effectiveness } \\
\text { rather than social } \\
\text { and } \\
\text { environmental } \\
\text { (16); } \\
\text { Despite interest } \\
\text { in developing } \\
\text { sustainability } \\
\text { indicators (58), } \\
\text { few studies } \\
\text { compare } \\
\text { sustainable } \\
\text { development of } \\
\text { specific areas for } \\
\text { different time } \\
\text { periods (24). }\end{array}$ \\
\hline Accessibility & $\begin{array}{l}\text { measurement issues ((57) use available } \\
\text { transportation, frequency, and travel time) and } \\
\text { the 'imagined' accessibility that } \\
\text { telecommunications offer (6); } \\
\text { market concentration in coastal shipping and its } \\
\text { impacts on accessibility (25); } \\
\text { and more technical approaches on managing } \\
\text { supply and demand with spatial information } \\
\text { systems (37), choice (46); (43) and travel } \\
\text { decisions (26). }\end{array}$ & $\begin{array}{l}\text { High levels of } \\
\text { transport market } \\
\text { concentration } \\
\text { affect severely } \\
\text { accessibility and } \\
\text { seasonality (57) } \\
\text { and for local } \\
\text { sustainable } \\
\text { development, as } \\
\text { extra costs, direct }\end{array}$ \\
\hline Transport & $\begin{array}{l}\text { - } \quad \text { supply (25); (37) and } \\
\text { - } \quad \text { demand (46); (26); (1); (49); (68); (43). }\end{array}$ & $\begin{array}{l}\text { and indirect, are } \\
\text { a permanent } \\
\text { factor that } \\
\text { burdens all }\end{array}$ \\
\hline
\end{tabular}




\begin{tabular}{|l|l|l|}
\hline $\begin{array}{c}\text { Theme / } \\
\text { sub-theme }\end{array}$ & Most important issue(s) presented & $\begin{array}{c}\text { Most important } \\
\text { findings }\end{array}$ \\
\hline & & $\begin{array}{l}\text { activities on and } \\
\text { of islands (43); } \\
(57) ;(26) .\end{array}$ \\
\hline Attractiveness & - only in (59) with the use of indicators and \\
& overall indexes for island administration units. & $\begin{array}{l}\text { Lack of decisive } \\
\text { information to } \\
\text { support local } \\
\text { development } \\
\text { decisions. }\end{array}$ \\
\hline
\end{tabular}


Figure 2: Classification of themes, sub-themes, and one or multiple Aegean islands.

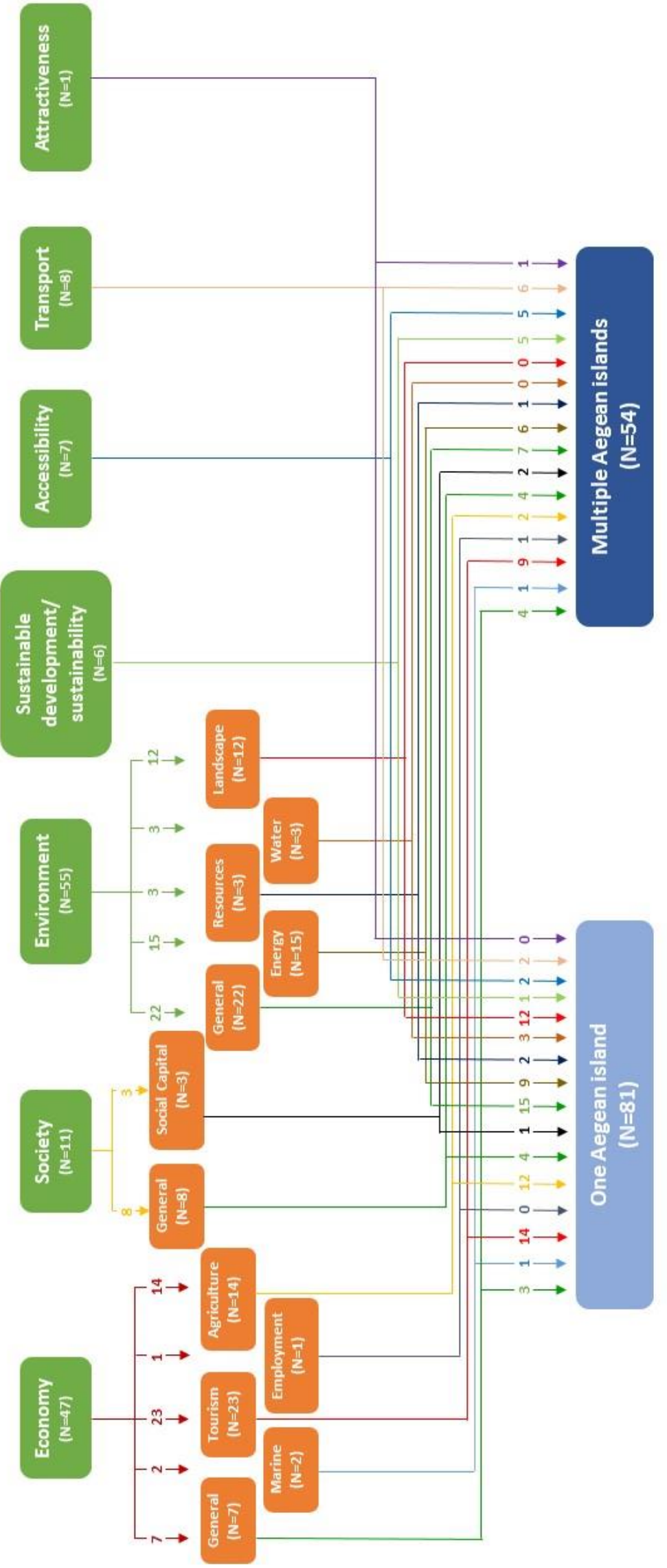




\section{Spilanis}

\section{Discussion}

The analysis presented here contributes a number of interesting and important results concerning sustainable local development not only for Aegean islands, but also for islands in general. The analysis also highlights gaps in the literature and widely covered topical areas.

Tourism stands out as the area with the best coverage. The literature covers various aspects of tourism well but is weak in terms of so-called 'alternative' forms (e.g., Andriotis, 2013; Spilanis \& Vayanni, 2003). Despite the obvious finding that tourism is very important as an economic, social, and environmental activity, the literature does not analyze in depth or even discuss implications, differences, and specificities of tourism on islands, whether the practice of tourism and its impacts are related to islandness (Pons \& Rullan, 2014). The related issue of 'second home' development and urban sprawl is important in terms of land cover (Kizos et al., 2017), but the relevant analysis in the literature is very limited and concerns just a few islands (e.g., Salvati, 2013, for Mykonos; Spilanis \& Karayiannis, 2009, for the Cyclades). Relatively 'new' and very popular subjects in the tourism literature (Kladou et al., 2015; Liang, 2014; Moore, 2015) also receive little discussion (Nazou, 2009; Stylidis et al., 2008).

Another well-covered issue is energy and water provision, for which islandness is indeed very important and influences the research and discussion approach. Apart from mostly technical contributions, interrelationships between economic and especially social aspects of energy issues are neglected (with the exception of Dimitropoulos \& Kontoleon, 2009; Manolakos et al., 2004; Oikonomou et al., 2009; Patlitzianas \& Kolybiris, 2012). This is an important omission, as 'success' or 'failure' of such systems is often an issue of local consensus, engagement, and participation (Mondol \& Koumpetsos, 2013). For us, this seems to be one of the areas on which future research should focus.

Human and social capital also receives very few references. Many approaches recognize that 'networking' and 'cooperation' are particularly important for islands, where human resources are often limited, and within different social groups (e.g., tourists and locals; Vousdoukas et al., 2009; Tampakis et al., 2012). The limited Greek experience in networking and partnership-building is also highlighted (Getimis \& Demetropoulou, 2004), as are the critical role of social agents (Galani-Moutafi, 2013) and non-state actors in policy-making, new forms of regional governance, partnershipbuilding (Getimis \& Demetropoulou, 2004), participatory planning (Balaras et al., 1999), and consensus-building (Sapountzaki \& Wassenhoven, 2005). What seems to be missing are assessments of the 'quantity' and 'quality' of human and social capital, an important omission for us.

Transport and accessibility are also popular themes and are unsurprisingly determined by islandness. Travel times and travel costs of alternative modes of transport play a significant role in choices (Polydoropoulou \& Litinas, 2007; Spilanis et al., Kizos \& Petsioti, 2012), along with the travelers' features (such as income, age, education, and occupation; Levy \& Panou, 2010; Polydoropoulou \& Litinas, 2007).

Cross-sectoral papers include efforts at integrated measurement of sustainable development with composite indicators and indexes. Despite interest in the development of sustainability indicators, their actual use as tools that can inform policy makers and help formulate policies seems very limited (Kondyli, 2010; Spilanis et al., 2009; Spilanis et al., 2013). Again, here, the particular theme is open for further 
research and applications that should provide 'digestible' information to policy-makers and suggest not only measurement instruments and tools, but also feasible applications.

Finally, an issue that we consider important is the lack of comparisons within islands (see, e.g., Armstrong et al., 2014) and between islands and similar continental areas. According to Baldacchino (2004, p. 278):

There is no better comparison for an island than another island. There may also be no better comparison for a mainland than an island, since the processes and dynamics that occur habitually on a mainland may be enhanced and exacerbated in an island setting.

Furthermore, in many areas like the sustainable local development, studies are also strengthened and enriched by an 'island-mainland' as well as an 'island-island' comparison or dialectic (such as cultural history, electricity generation, waste management, or price differentials; Baldacchino, 2006). These would allow more realistic comparison of economic and social issues and would also shed more light on certain issues pertaining to islandness that the literature seems to take for granted or simply ignores (see e.g., Spilanis et al., 2012, for availability of everyday services). Some references that attempt to take these issues into account are revelatory: comparisons within islands (Kondyli, 2010; Salvati, 2013; Nazou, 2009); and islands and similar settlements in continental Greece (Kizos \& Iosifides, 2007; Polymeros et al., 2014; Spilanis et al., 2012).

Moreover, "islands are not islands, in the sense that they are not closed unto themselves. [...] The conception and expression of island identity, as well as its size, are part of an ongoing dialectic between the geographic and the political" (Baldacchino, 2004, p. 273-4). This is exactly what DeLoughrey (2001, p. 23) usefully labels "a system of archipelagraphy, a historiography that considers chains of islands in fluctuating relationship to their surrounding seas, islands and continents" (see also Pugh, 2016; Stratford et al., 2011). Constantakopoulou (2007, p. 2) gives island networking an important role in the history of the Aegean, emphasizing that "islands were understood as distinct 'closed' worlds, ideal locations for the extraordinary and the bizarre, but at the same time they were also perceived as parts of a complex reality of interaction."

In our literature review, we reinforced the statement made by several authors that in "the field of island studies, the archipelago remains one of the least examined metageographical concepts" (Stratford et al., 2011, p. 118; see also Pugh, 2013). The Aegean is one of the most famous archipelagos in the world but rarely identified as such. According to Karampela et al. (2015, p. 46-47):

For the Aegean islands in general, an international image and brand already exists, as an archipelago. But, despite historical, geographical, climatic, linguistic, landscape and other similarities, there remain considerable differences in perception, representation and imagination within this ancient archipelago [...] Within the archipelago, the image of smaller islands is overshadowed by that of larger ones or of the archipelago itself.

Figure 2 displays this island focus in the literature review with 81 cases for one Aegean island versus 54 cases for multiple islands. This highlights the necessity of moving beyond thinking of islands as 'closed' worlds and instead thinking of them in terms of islands interactions, archipelagos, and aquapelagos. Reframing the 
Archipelago allows for a broader discussion and overcomes the geographical challenges presented by the scattering of islands, which is recognized as key to the sustainable development (Dean, 2016). Hayward (2012, p. 6) refers to the special nature of archipelagic planning and emphasizes "the aquapelago as an entity constituted by human presence in and utilization of the environment (rather than as an 'objective' geographical entity)," terms that are missing from our literature review. Research addressing aspects of the relationship between fisheries and societies perhaps represents the most obvious area; see the approach of Hayward (2011). Also, "islands and archipelagos pose unique challenges for tourism policy. While tourism development in islands is well studied, little attention has been given to archipelagos and their special challenges" (Bardolet \& Sheldon, 2008, p. 900; see also Baldacchino \& Ferreira, 2013; see also Baldacchino, 2015, for archipelago tourism and Grydehøj, 2008, 2011, for the place-branding process that has been undertaken in the Shetland archipelago).

\section{Conclusion}

In this paper, we wished to provide foundations for a reappraisal of sustainable development on/for islands with the use of specific case studies (thematic and crosssectoral) for a specific area of islands, namely the Aegean. This is the only review paper with meta-analysis focused exclusively on Aegean islands. It thus joins other meta-analyses of island studies literature with different topical focuses, such as Baldacchino (2004), Depraetere (2008), Fletcher (2011), Grydehøj et al., (2015), Lewis (2009), and Mezzana et al. (2012). One of our most important findings refers to the difficulty of handling the conceptual, methodological, and empirical diversity found in the literature. Sustainable development remains an arena of contested, contrasted, and sometimes contradictory meanings and operationalizations (Abson et al., 2014; Fischer et al., 2007; Fredericks, 2013; Landerretche et al., 2017; Mori \& Christodoulou, 2012; Parris \& Kates, 2003). But, at the same time, this diversity should be also welcomed as evidence of plurality and as an indication that, just as there are many ways of studying aspects of sustainable development, there also seem to be many alternative pathways towards achieving it. Our examples clearly indicate this.

This article can serve as a basis and a tool for future research because it highlights gaps in the literature concerning Aegean islands: (a) cross-sectoral approaches, (b) social aspects of sustainable development, and (c) links between environmental aspects and economic and especial social aspects. In the words of Baldacchino (2006, p. 10), "Island studies' need/should not be focused only on islands themselves, but also on relations between islands and mainlands. [...] Seeing islands as part of complex and cross-cutting systems of regional and global interaction should be one of the strengths of island studies." Baldacchino (2006) thus emphasizes the potential for studying archipelagoes (see also Depraetere, 2008) as well as the opportunities islands provide for comparisons and alternative models of development. This itself highlights the archipelagic characteristics with which the literature on sustainable local development should be engaged. According to Koutsouris (1998), the local is the opposite of the global, being at the same time the victim of the global. In the era of globalization, schematically speaking, business becomes global and reactions arise at the local level. Globalization both standardizes and homogenizes as well as highlights and invigorates local initiatives and identities (Baldacchino, 2004; Hay, 2006).

Despite the contribution of this paper, there are some limitations. The study uses the Scopus database, which despite being authoritative (Sainaghi et al., 2017) is 
not exhaustive of all the possible publications relating to sustainable local development on Aegean islands, especially chapters in edited volumes that are not yet fully integrated into scientific databases. Similarly, we do not include textbooks, 'grey' literature, and sources in Greek in our sample. Notwithstanding these limitations, our sample is valid within its scope, and will help to identify salient longitudinal themes in its field for the purposes of this paper.

\section{Acknowledgements}

Part of the work of this paper was supported by the Integrated Program for Island Research (IPIR) of the Program: 'The University of the Aegean, the prominent and driving factor for the economic and social growth of the wide Aegean area' of the Operational Program 'Education and Lifelong Learning', which is co-funded by the European Union (European Social Fund) and National Resources. An earlier draft of this paper was presented at an ISISA Islands of the World Conference held in Mytilene, Lesvos, Greece, in May 2016. The usual disclaimers apply.

\section{References in the sample}

1. Andriotis, K. (2013). The 'antinomian' travel counterculture of Gavdos. An alternative mode of travelling. Annals of Tourism Research, 40(1), 40-58. https://doi.org/10.1016/j.annals.2012.08.002

2. Arhonditsis, G., Giourga, C., \& Loumou, A. (2000). Ecological patterns and comparative nutrient dynamics of natural and agricultural Mediterranean-type ecosystems. Environmental Management, 26(5), 527-537. https://doi.org/10.1007/s002670010110

3. Arhonditsis, G., Giourga, C., Loumou, A., \& Koulouri, M. (2002). Quantitative assessment of agricultural runoff and soil erosion using mathematical modeling: Applications in the Mediterranean region. Environmental Management, 30(3), 434-453. https://doi.org/10.1007/s00267-001-2692-1

4. Balaras, C.A., Santamouris, M., Asimakopoulos, D.N., Argiriou, A.A., Paparsenos, G., \& Gaglia, A. G. (1999). Energy policy and an action plan for renewable energy sources (RES) for the hellenic islands of the north Aegean region. Energy, 24(4), 335-350. https://doi.org/10.1016/S0360-5442(98)00079-6

5. Bevan, A., Conolly, J., Colledge, S., Frederick, C., Palmer, C., Siddall, R., \& Stellatou, A. (2013). The long-term ecology of agricultural terraces and enclosed fields from Antikythera, Greece. Human Ecology, 41(2), 255-272. https://doi.org/10.1007/s10745-012-9552-x

6. Bletsas, M. (2004). Wirefree in Patmos. BT Technology Journal, 22(4), 25-31. https://doi.org/10.1023/B:BTTJ.0000047580.44313.bc

7. Brofas, G., Karetsos, G., Dimopoulos, P., \& Tsagari, C. (2006). The natural environment of cupressus sempervirens in Greece as a basis for its use in the Mediterranean region. Land Degradation and Development, 17(6), 645-659. https://doi.org/10.1002/ldr.750

8. Dikou, A., Papapanagiotou, E., \& Troumbis, A. (2011). Integrating landscape ecology and geoinformatics to decipher landscape dynamics for regional planning. Environmental Management, 48(3), 523-538. https://doi.org/10.1007/s00267-011$\underline{9714-4}$ 
9. Dimitropoulos, A., \& Kontoleon, A. (2009). Assessing the determinants of local acceptability of wind-farm investment: A choice experiment in the Greek Aegean $\begin{array}{llll}\text { islands. } & \text { Energy } & \text { Policy, } & \text { 37(5), }\end{array}$ https://doi.org/10.1016/j.enpol.2009.01.002

10. Frangou, M., Tsoutsos, T., \& Sakellariou, N. (2012). Sustainability assessment of a solar thermal power project in Mediterranean application in the island of Crete. Ecological Indicators, 18, 379-386. https://doi.org/10.1016/j.ecolind.2011.12.003

11. Freedman, P. (2011). Mastic: A Mediterranean luxury product. Mediterranean Historical Review, 26(1), 99-113. https://doi.org/10.1080/09518967.2010.536673

12. Fyllas, N.M., Politi, P.I., Galanidis, A., Dimitrakopoulos, P.G., \& Arianoutsou, M. (2010). Simulating regeneration and vegetation dynamics in Mediterranean coniferous forests. Ecological Modelling, 221(11), 1494-1504. https://doi.org/10.1016/j.ecolmodel.2010.03.003

13. Galani-Moutafi, V. (2013). Rural space (re)produced-practices, performances and visions: A case study from an Aegean island. Journal of Rural Studies, 32, 103-113. https://doi.org/10.1016/j.jrurstud.2013.04.007

14. Gavalas, V.S. (2005). Family formation and dissolution in an Aegean island. Journal of Biosocial Science, 37(3), 351-370. https://doi.org/10.1017/S0021932004006789

15. Getimis, P., \& Demetropoulou, L. (2004). Towards new forms of regional governance in Greece: The southern Aegean islands. Regional and Federal Studies, 14(3), 355-378. https://doi.org/10.1080/1359756042000261351

16. Giourga, C., Loumou, A., Tsevreni, I., \& Vergou, A. (2008). Assessing the sustainability factors of traditional olive groves on Lesvos island, Greece (sustainability and traditional cultivation). GeoJournal, 73(2), 149-159. https://doi.org/10.1007/s10708-008-9195-Z

17. Gournellos, T., Evelpidou, N., \& Vassilopoulos, A. (2004). Developing an erosion risk map using soft computing methods (case study at Sifnos island). Natural Hazards, 31(1), 63-83. https://doi.org/10.1023/B:NHAZ.0000020277.28291.06

18. Kalabokidis, K., Iosifides, T., Henderson, M., \& Morehouse, B. (2008). Wildfire policy and use of science in the context of a socio-ecological system on the Aegean archipelago. Environmental Science and Policy, 11(5), 408-421. https://doi.org/10.1016/j.envsci.2008.01.006

19. Kasselouri, B., Kambezidis, H., Konidari, P., \& Zevgolis, D. (2011). Environmental, economic and social aspects of the electrification on the noninterconnected islands of the Aegean sea. Paper presented at the Energy Procedia, 6, 477-486. https://doi.org/10.1016/j.egypro.2011.05.055

20. Kizos, T., \& Iosifides, T. (2007). The contradictions of agrotourism development in Greece: Evidence from three case studies. South European Society and Politics, 12(1), 59-77. https://doi.org/10.1080/13608740601155443

21. Kizos, T., \& Koulouri, M. (2010). Same land cover, same land use at the large scale, different landscapes at the small scale: Landscape change in olive plantations on Lesvos island, Greece. Landscape Research, 35(4), 449-467. https://doi.org/10.1080/01426390802048297

22. Kizos, T., \& Vakoufaris, H. (2011). Valorisation of a local asset: The case of olive oil on Lesvos island, Greece. Food Policy, 36(5), 704-713. https://doi.org/10.1016/j.foodpol.2011.06.005

23. Kizos, T., Koulouri, M., Vakoufaris, H., \& Psarrou, M. (2010). Preserving characteristics of the agricultural landscape through agri-environmental policies: 
The case of cultivation terraces in Greece. Landscape Research, 35(6), 577-593. https://doi.org/10.1080/01426397.2010.519434

24. Kondyli, J. (2010). Measurement and evaluation of sustainable development. A composite indicator for the islands of the north Aegean region, Greece. Environmental Impact Assessment Review, 30(6), 347-356. https://doi.org/10.1016/j.eiar.2009.08.006

25. Lekakou, M.B., \& Vitsounis, T.K. (2011). Market concentration in coastal shipping and limitations to island's accessibility. Research in Transportation Business and Management, 2, 74-82. https://doi.org/10.1016/j.rtbm.2011.10.001

26. Levy, S., \& Panou, C. (2010). To travel or not to travel: a study of islanders' trips to the mainland. 12th WCTR, July 11-15, 2010-Lisbon, Portugal.

27. Loumou, A., Giourga, C., Dimitrakopoulos, P., \& Koukoulas, S. (2000). Tourism contribution to agro-ecosystems conservation: The case of Lesbos island, Greece. Environmental Management, 26(4), 363-370. https://doi.org/10.1007/s002670010093

28. Manolakos, D., Papadakis, G., Papantonis, D., \& Kyritsis, S. (2001). A simulationoptimisation programme for designing hybrid energy systems for supplying electricity and fresh water through desalination to remote areas case study: The Merssini village, Donoussa island, Aegean sea, Greece. Energy, 26(7), 679-704. https://doi.org/10.1016/S0360-5442(01)00026-3

29. Manolakos, D., Papadakis, G., Papantonis, D., \& Kyritsis, S. (2004). A stand-alone photovoltaic power system for remote villages using pumped water energy storage. Energy, 29(1), 57-69. https://doi.org/10.1016/j.energy.2003.08.008

30. Margaris, N S. (1992). Primary sector and environments in the Aegean islands, Greece. Environmental Management, 16(5), 569-574. https://doi.org/10.1007/BF02589011

31. Meliou, E., \& Maroudas, L. (2010). Understanding tourism development: A representational approach. Tourismos, 5(2), 115-127.

32. Mihalakakou, G., Psiloglou, B., Santamouris, M., \& Nomidis, D. (2002). Application of renewable energy sources in the Greek islands of the south Aegean sea. Renewable Energy, 26(1), 1-19. https://doi.org/10.1016/S0960$\underline{1481(01) 00111-2}$

33. Mondol, J.D., \& Koumpetsos, N. (2013). Overview of challenges, prospects, environmental impacts and policies for renewable energy and sustainable development in Greece. Renewable and Sustainable Energy Reviews, 23, 431-442. https://doi.org/10.1016/j.rser.2013.01.041

34. Nazou, D. (2009). Shifted identities in tourism: When Mykonos 'travels' to Thailand for holidays. Tourismos, 4(3), 81-98.

35. Oikonomou, E.K., Kilias, V., Goumas, A., Rigopoulos, A., Karakatsani, E., Damasiotis, M., \& Marini, N. (2009). Renewable energy sources (RES) projects and their barriers on a regional scale: The case study of wind parks in the Dodecanese islands, Greece. Energy Policy, 37(11), 4874-4883. https://doi.org/10.1016/j.enpol.2009.06.050

36. Palaiologou, P., Kalabokidis, K., Haralambopoulos, D., Feidas, H., \& Polatidis, H. (2011). Wind characteristics and mapping for power production in the island of Lesvos, Greece. Computers and Geosciences, 37(7), 962-972. https://doi.org/10.1016/j.cageo.2010.05.025

37. Pantazis, D.N., Stratakis, P., Karathanasis, C., \& Gkadolou, E. (2013). Design of a coastal transport integrated system: Preliminary system specifications and data collection for the Aegean sea islands doi:10.1007/978-3-642-39649-6-19. 
38. Papanastasiou, J. A., Lazaridis, I. T., \& Noulas, A. (2006). Tourists' preferences for quality of services: Empirical investigation of Lesvos, Samos and Chios islands. Tourismos, 1(2), 95-101.

39. Papanis, E., \& Kitrinou, E. (2011). The role of alternative types of tourism and ICT-strategy for the tourism industry of Lesvos. Tourismos, 6(2), 313-331.

40. Papastamoulos, K., Vrettos, E., Papathanassiou, S., \& Boulaxis, N. (2010). Introduction of battery energy storage in a small island grid to increase wind energy penetration levels. Paper presented at the European Wind Energy Conference and Exhibition 2010, EWEC 2010, 6, 4533-4543.

41. Patlitzianas, K.D., \& Kolybiris, C. (2012). Effective financing for provision of renewable electricity and water supply on islands. Energy for Sustainable Development, 16(1), 120-124. https://doi.org/10.1016/j.esd.2011.11.003

42. Petanidou, T., Kizos, T., \& Soulakellis, N. (2008). Socioeconomic dimensions of changes in the agricultural landscape of the Mediterranean basin: A case study of the abandonment of cultivation terraces on Nisyros island, Greece. Environmental Management, 41(2), 250-266. https://doi.org/10.1007/s00267-007-9054-6

43. Polydoropoulou, A., \& Litinas, N. (2007). Demand models for Greek passenger shipping. Research in Transportation Economics, 21, 297-322. https://doi.org/10.1016/S0739-8859(07)21009-1

44. Polymeros, K., Kaimakoudi, E., Mitsoura, A., Nikouli, E., \& Mente, E. (2014). The determinants of consumption for organic aquaculture products - evidence from Greece. Aquaculture Economics and Management, 18(1), 45-59. https://doi.org/10.1080/13657305.2014.855954

45. Manolakos, D., Mohamed, E. S., Karagiannis, I., \& Papadakis, G. (2008). Technical and economic comparison between PV-RO system and RO-solar rankine system. case study: Thirasia island. Desalination, 221(1-3), 37-46. https://doi.org/10.1016/j.desal.2007.01.066

46. Rigas, K. (2009). Boat or airplane? Passengers' perceptions of transport services to islands. The example of the Greek domestic leisure market. Journal of Transport Geography, 17(5), 396-401. https://doi.org/10.1016/j.jtrangeo.2008.07.005

47. Robolis, S., \& Xideas, E. (1996). The economic determinants of Greek return migration to the islands of the east Aegean. International Migration, 34(2), 297314. https://doi.org/10.1111/j.1468-2435.1996.tb00527.x

48. Salvati, L. (2013). Rural sprawl, Mykonian style: A scaling paradox. International Journal of Sustainable Development and World Ecology, 20(2), 109-115. https://doi.org/10.1080/13504509.2013.765522

49. Sambracos, E., \& Rigas, K. (2007). Passenger reactions to market deregulation: First results from the experience of the Greek islands market. Journal of Air Transport Management, 13(2), 61-66. https://doi.org/10.1016/i.jairtraman.2006.11.007

50. Sapountzaki, K., \& Wassenhoven, L. (2005). Consensus building and sustainability: Some lessons from an adverse local experience in Greece. Environment, Development and Sustainability, 7(4), 433-452. https://doi.org/10.1007/s10668-004-2376-0

51. Sdrali, D., \& Chazapi, K. (2007). Cultural tourism in a Greek insular community: The residents' perspective. Tourismos, 2(2), 61-75.

52. Sevenant, M., \& Antrop, M. (2007). Settlement models, land use and visibility in rural landscapes: Two case studies in Greece. Landscape and Urban Planning, 80(4), 362-374. https://doi.org/10.1016/j.landurbplan.2006.09.004 
53. Spanou, S., Tsegenidi, K., \& Georgiadis, T. (2012). Perception of visitors' environmental impacts of ecotourism: A case study in the valley of butterflies protected area, Rhodes island, Greece. International Journal of Environmental Research, 6(1), 245-258.

54. Spilanis, I.P., \& Karayiannis, O.P. (2009). Tourism and environment: Pressures of tourism related construction activity on the natural environment of host areasattempting a survey in the Cyclades. Tourismos, 4(4), 17-34.

55. Spilanis, I., \& Vayanni, H. (2004). Sustainable tourism: Utopia or necessity? The role of new forms of tourism in the Aegean islands. In B. Bramwell (Ed.) Coastal mass tourism: Diversification and sustainable development in southern Europe (pp. 269-291). Channel View Publications.

56. Spilanis, I., Kizos, T., \& Giordano, B. (2013). The effectiveness of european regional development fund projects in greece: Views from planners, management staff and beneficiaries. European Urban and Regional Studies, 23(2), 182-197. https://doi.org/10.1177/0969776413498761

57. Spilanis, I., Kizos, T., \& Petsioti, P. (2012). Accessibility of peripheral regions: Evidence from Aegean islands (Greece). Island Studies Journal, 7(2), 199-214.

58. Spilanis, I., Kizos, T., Koulouri, M., Kondyli, J., Vakoufaris, H., \& Gatsis, I. (2009). Monitoring sustainability in insular areas. Ecological Indicators, 9(1), 179187. https://doi.org/10.1016/j.ecolind.2008.03.003

59. Spilanis, I., Kizos, T., Vaitis, M., \& Koukourouvli, N. (2013). Measuring the economic, social and environmental performance of European island regions: Emerging issues for European and regional policy. European Planning Studies, 21(12), 1998-2019. https://doi.org/10.1080/09654313.2012.722970

60. Stamatiou, E., \& Lagos, D. (2006). Promotion of tourism development in environmentally vulnerable areas - The case of border \& Less Favored Regions (LFRs). Journal of Environmental Protection \& Ecology, 7(2), 250-259.

61. Stamatiou, E., \& Lagos, D. (2005). Land planning for small Aegean islands with tourism expansion capabilities. IASME Transactions - WSEAS Journal, 5(2), 729737.

62. Stylidis, D., Terzidou, M., \& Terzidis, K. (2008). Islands and destination image: The case of Ios. Tourismos, 3(1), 180-199.

63. Symeonakis, E., Caccetta, P., Koukoulas, S., Furby, S., \& Karathanasis, N. (2012). Multi-temporal land-cover classification and change analysis with conditional probability networks: The case of Lesvos island (Greece). International Journal of Remote Sensing, 33(13), 4075-4093. https://doi.org/10.1080/01431161.2011.640961

64. Tampakis, S., Manolas, E., \& Tampakis, V. (2012). Assessing tourist infrastructure in the island of Skiathos: The views of locals and visitors. Tourismos, 7(1), 175191.

65. Tegou, L., Polatidis, H., \& Haralambopoulos, D.A. (2010). Environmental management framework for wind farm siting: Methodology and case study. Journal of Environmental Management, 91(11), 2134-2147. https://doi.org/10.1016/j.jenvman.2010.05.010

66. Tsartas, P., \& Lagos, D. (2007). Regional structuring of tourism employment in Greece. Asian Journal of Tourism and Hospitality Research 1(1), 139-149.

67. Tsartas, P., \& Lagos, D. (2004). Critical appraisal of regional tourism development and policy in Greece. Journal of Applied Economics \& Management, 2(1), 15-31. 
68. Tsekeris, T. (2009). Dynamic analysis of air travel demand in competitive island markets. Journal of Air Transport Management, 15(6), 267-273. https://doi.org/10.1016/j.jairtraman.2008.11.008

69. Tselentis, B.S., Prokopiou, D.G., \& Toanoglou, M. (2012). Comparative analysis of carrying capacity indices for the central Aegean islands. European Research Studies, $X V(1), 155-170$.

70. Tzanopoulos, J., \& Vogiatzakis, I.N. (2011). Processes and patterns of landscape change on a small Aegean island: The case of Sifnos, Greece. Landscape and Urban Planning, 99(1), 58-64. https://doi.org/10.1016/j.landurbplan.2010.08.014

71. Tzanopoulos, J., Mitchley, J., \& Pantis, J.D. (2007). Vegetation dynamics in abandoned crop fields on a Mediterranean island: Development of succession model and estimation of disturbance thresholds. Agriculture, Ecosystems and Environment, 120(2-4), 370-376. https://doi.org/10.1016/j.agee.2006.10.011

72. Vakoufaris, H. (2010). The impact of ladotyri Mytilinis PDO cheese on the rural development of Lesvos island, Greece. Local Environment, 15(1), 27-41. https://doi.org/10.1080/13549830903406057

73. Vakoufaris, H., Kizos, T., Spilanis, I., Koulouri, M., \& Zacharaki, A. (2007). Women's cooperatives and their contribution to the local development of the north Aegean region, Greece. Journal of Rural Cooperation, 35(1), 19-41.

74. Vavoulidou, E., Avramides, E.J., Dimirkou, A., \& Papadopoulos, P. (2006). Influence of different cultivation practices on the properties of volcanic soils on Santorini island, Greece. Communications in Soil Science and Plant Analysis, 37(15-20), 2857-2866. https://doi.org/10.1080/00103620600832837

75. Vlachos T., Diakomihalis M., \& Lagos D. (2011). Taxation and Competitiveness in the Hotel branch: The case of 4 and 5 star hotels of Kos island, Greece. Journal of Management Science and Regional Development. 7, 125-141.

76. Voultsiadou, E., Vafidis, D., \& Antoniadou, C. (2008). Sponges of economical interest in the eastern Mediterranean: An assessment of diversity and population density. Journal of Natural History, 42(5-8), 529-543. https://doi.org/10.1080/00222930701835506

77. Vousdoukas, M.I., Velegrakis, A.F., Kontogianni, A., \& Makrykosta, E. (2009). Implications of the cementation of beach sediments for the recreational use of the beach. Tourism Management, 30(4), 544-552. https://doi.org/10.1016/j.tourman.2008.09.007

78. Zafirakis, D., \& Kaldellis, J.K. (2009). Economic evaluation of the dual mode CAES solution for increased wind energy contribution in autonomous island networks. Energy Policy, 37(5), 1958-1969. https://doi.org/10.1016/j.enpol.2009.01.033

79. Zissi, A., Tseloni, A., Skapinakis, P., Savvidou, M., \& Chiou, M. (2010). Exploring social capital in rural settlements of an islander region in Greece. Journal of Community and Applied Social Psychology, 20(2), 125-138.

80. Perdicoulis, A. (1997). A pilot method for comparing the development alternatives of Syros, Greece. European Environment, 7(5), 156-161. https://doi.org/10.1002/(SICI)1099-0976(199709)7:5<156::AID-

EET123>3.0.CO;2-0

\section{Other references}

Abson, D.J., von Wehrden, H., Baumgärtner, S., Fischer, J., Hanspach, J., Härdtle, W., Heinrichs, H., Klein, A.M., Lang, D.J., Martens, P., \& Walmsley, D. (2014). 
Ecosystem services as a boundary object for sustainability. Ecological Economics, 103, 29-37. https://doi.org/10.1016/j.ecolecon.2014.04.012

Armstrong, H., Ballas, D., \& Staines, A. (2014). A comparative classification of labour market characteristics of British and Greek small islands. European Urban and Regional Studies, 21(2), 222-248. https://doi.org/10.1177/0969776412448094

Baldacchino, G. (Ed.) (2015). Archipelago tourism: policies and practices. Farnham: Ashgate.

Baldacchino, G. (2006). Islands, island studies, island studies journal. Island Studies Journal, 1(1), 3-18.

Baldacchino, G. (2004). The coming of age of island studies. Tijdschrift voor economische en sociale geografie, 95(3), 272-283. https://doi.org/10.1111/j.14679663.2004.00307.x

Baldacchino, G., \& Ferreira, E.C.D. (2013). Competing notions of diversity in archipelago tourism: transport logistics, official rhetoric and inter-island rivalry in the Azores. Island Studies Journal, 8(1), 84-104.

Baldacchino, G., \& Kelman, I. (2014). Critiquing the Pursuit of Island Sustainability. Shima: The International Journal of Research into Island Cultures, 8(2), 1-21.

Bardolet, E., \& Sheldon, P.J. (2008). Tourism in archipelagos: Hawai'i and the Balearics. Annals of Tourism Research, 35(4), 900-923. https://doi.org/10.1016/j.annals.2008.07.005

Constantakopoulou, C. (2007). The Dance of the Islands: Insularity, Networks, the Athenian Empire, and the Aegean World. Oxford: Oxford University Press. https://doi.org/10.1093/acprof:oso/9780199215959.001.0001

Dean, R. (2016). Book review: Archipelago Tourism: Policies and Practices. The International Journal of Bahamian Studies, 22, 83-84. https://doi.org/10.15362/ijbs.v22i0.263

DeLoughrey, E. (2001). 'The litany of islands, the rosary of archipelagoes': Caribbean and Pacific archipelagraphy. ARIEL: A Review of International English Literature, 32(1), 21-52.

Depraetere, C. (2008). The challenge of Nissology: A global outlook on the world archipelago. Part II: the global and scientific vocation of Nissology. Island Studies Journal, 3(1), 17-36.

Fischer, J., Manning, A.D., Steffen, W., Rose, D.B., Daniell, K., Felton, A., Garnett, S., Gilna, B., Heinsohn, R., Lindenmayer, D.B., MacDonald, B., Mills, F., Newell, B., Reid, J., Robin, L., Sherren, K., \& Wade, A. (2007). Mind the sustainability gap. Trends in Ecology \& Evolution, 22(12), 621-624. https://doi.org/10.1016/j.tree.2007.08.016

Fletcher, L. (2011). '... some distance to go': a critical survey of Island Studies. New Literatures Review, (47-48), 17-34.

Fredericks, S.E. (2013). Measuring and evaluating sustainability: Ethics in sustainability indexes. New York: Routledge.

Girard, L.F., \& Nijkamp, P. (2009). Narrow escapes: pathways to sustainable Local cultural tourism. In L.F. Girard \& P. Nijkamp (Eds.), Cultural tourism and sustainable local development (pp. 1-9). Farnham: Ashgate.

Grydehøj, A. (2011). Making the most of smallness: economic policy in microstates and sub-national island jurisdictions. Space and Polity, 15(3), 183-196. https://doi.org/10.1080/13562576.2011.692578

Grydehøj, A. (2008). Branding from above: generic cultural branding in shetland and other islands. Island Studies Journal, 3(2), 175-198.Grydehøj, A., \& Kelman, I. (2017). The 
eco-island trap: climate change mitigation and conspicuous sustainability. Area, 49(1), 106-113. https://doi.org/ 10.1111/area.12300

Grydehøj, A., Pinya, X.B., Cooke, G., Doratli, N., Elewa, A., Kelman, I., Pugh, J., Schick, L., \& Swaminathan, R. (2015). Returning from the horizon: introducing urban island studies. Urban Island Studies, 1, 1-19. https://doi.org/10.20958/uis.2015.1

Hay, P. (2006). A phenomenology of islands. Island Studies Journal, 1(1), 19-42.

Hayward, P. (2012). Aquapelagos and aquapelagic assemblages. Shima, 6(1), 1-11.

Hayward, P. (2011). Salmon aquaculture, cuisine and cultural disruption in Chiloe. Locale: The Australasian-Pacific Journal of Regional Food Studies, 1(1), 87-110.

Huang, B., Ouyang, Z., Zheng, H., Zhang, H., \& Wang, X. (2008). Construction of an ecoisland: A case study of Chongming Island, China. Ocean and Coastal Management, 51(8-9), 575-588. https://doi.org/10.1016/j.ocecoaman.2008.06.007

Karampela, S., Kizos, T., \& Papatheodorou, A. (2015). Patterns transportation for tourists and residents in the Aegean Archipelago, Greece. In G. Baldacchino (Ed.) Archipelago tourism: policies and practices (pp. 35-50). Farnham: Ashgate.

Kizos, T., Tsilimigkas, G., \& Karampela, S. (2017). What drives built-up area expansion on islands? Using soil sealing indicators to estimate built-up area patterns on Aegean Islands, Greece. Tijdschrift voor economische en sociale geografie. https://doi.org/10.1111/tesg.12244

Kladou, S., Giannopoulos, A.A., \& Mavragani, E. (2015). Destination Brand Equity Research from 2001 to 2012. Tourism Analysis, 20(2), 189-200. https://doi.org/10.3727/108354215X14265319207399

Koutsouris, A. (1998). Networking for a sustainable future: The case of development agencies. Rural and farming systems analyses: Environmental perspectives, 114-125.

Landerretche, O., Leiva, B., Vivanco, D., \& López, I. (2017). Welcoming uncertainty: A probabilistic approach to measure sustainability. Ecological Indicators, 72, 586-596. https://doi.org/10.1016/j.ecolind.2016.08.050

Lewis, J. (2009). An island characteristic: Derivative vulnerabilities to indigenous and exogenous hazards. Shima, 3(1), 3-15.

Liang, A.R.D. (2014). Assessing the impact of co-branding of island destination and tourism activities on tourists' reactions. Current Issues in Tourism, 17, 1-16.

Mezzana, D., Lorenz, A., \& Kelman, I. (2012). Islands and islandness in rock music lyrics. Island Studies Journal, 7(1), 69-98.

Moore, A. (2015). Islands of Difference: Design, Urbanism, and Sustainable Tourism in the Anthropocene Caribbean. The Journal of Latin American and Caribbean Anthropology, 20, 513-532. https://doi.org/10.1111/jlca.12170

Mori, K., \& Christodoulou, A. (2012). Review of sustainability indices and indicators: Towards a new city sustainability index (CSI). Environmental Impact Assessment Review, 32(1), 94-106. https://doi.org/10.1016/j.eiar.2011.06.001

Parris, T.M., \& Kates, R.W. (2003). Characterizing and measuring sustainable development. Annual Review of environment and resources, 28(1), 559-586. https://doi.org/10.1146/annurev.energy.28.050302.105551

Pons, A., \& Rullan, O. (2014). Artificialization and islandness on the Spanish tourist coast. Miscellanea Geographica, 18(1), 5-16. https://doi.org/10.2478/mgrsd-2014-0010

Pugh, J. (2016). The relational turn in island geographies: bringing together island, sea and ship relations and the case of the Landship. Social \& Cultural Geography. https://doi.org/10.1080/14649365.2016.1147064

Pugh, J. (2013). Island movements: thinking with the archipelago. Island Studies Journal, $8(1), 9-24$. 
Rodríguez, J.R.O., Parra-López, E., \& Yanes-Estévez, V. (2008). The sustainability of island destinations: Tourism area life cycle and teleological perspectives. The case of $\begin{array}{llll}\text { Tenerife. } & \text { Tourism } & \text { Management, } & \text { 29(1), }\end{array}$ https://doi.org/10.1016/j.tourman.2007.04.007

Sainaghi, R., Phillips, P., \& Zavarrone, E. (2017). Performance measurement in tourism firms: A content analytical meta-approach. Tourism Management, 59, 36-56. https://doi.org/10.1016/j.tourman.2016.07.002

Spilanis, I., \& Kizos, T. (Eds.) (2015). Atlas ton Nision [Atlas of the Islands], University of the Aegean, Mytilini [in Greek].

Stratford, E., Baldacchino, G., McMahon, E., Farbotko, C., \& Harwood, A. (2011). Envisioning the archipelago. Island Studies Journal, 6(2), 113-130. 